\title{
Hospitality Fresh Graduates' Competency and Hotel Job Offer Decisions
}

\author{
Nurfarhanah Hasri, Farah Amira Md Din, Abdul Hannan Same, Raflie \\ Jakeriah \& Mohd Onn Rashdi Abd Patah
}

To Link this Article: http://dx.doi.org/10.6007/IJARBSS/v11-i16/11212 DOI:10.6007/IJARBSS/v11-i16/11212

Received: 04 July 2021, Revised: 26 July 2021, Accepted: 14 August 2021

Published Online: 06 September 2021

In-Text Citation: (Hasri et al., 2021)

To Cite this Article: Hasri, N., Din, F. A. M., Same, A. H., Jakeriah, R., \& Patah, M. O. R. A. (2021). Hospitality Fresh Graduates' Competency and Hotel Job Offer Decisions. International Journal of Academic Research in Business and Social Sciences, 11(16), 10-26.

Copyright: (C) 2021 The Author(s)

Published by Human Resource Management Academic Research Society (www.hrmars.com)

This article is published under the Creative Commons Attribution (CC BY 4.0) license. Anyone may reproduce, distribute, translate and create derivative works of this article (for both commercial and non-commercial purposes), subject to full attribution to the original publication and authors. The full terms of this license may be seen at: http://creativecommons.org/licences/by/4.0/legalcode

Special Issue Title: Contemporary Issues in Tourism and Hospitality industry, 2021, Pg. 10 - 26

Full Terms \& Conditions of access and use can be found at http://hrmars.com/index.php/pages/detail/publication-ethics 


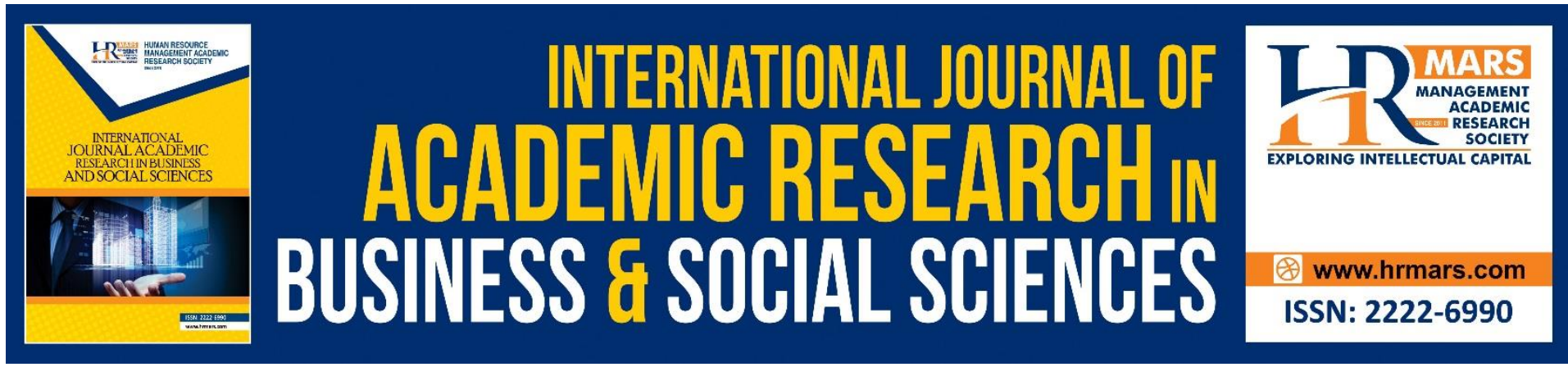

\title{
Hospitality Fresh Graduates' Competency and Hotel Job Offer Decisions
}

\author{
Nurfarhanah Hasri, Farah Amira Md Din, Abdul Hannan Same, \\ Raflie Jakeriah \& Mohd Onn Rashdi Abd Patah \\ Faculty of Hotel and Tourism Management Universiti Teknologi MARA, Cawangan Selangor, \\ Malaysia \\ Email: onn@uitm.edu.my
}

\begin{abstract}
Fresh graduates are the future generation that will keep the hotel industry regain its ground in this uncertain pandemic era. Hotels need to recruit prospective employees with desired skills set which could increase their performance in delivering the best service to their guest. This study was conducted to help fresh graduates to see what is the element of competency that hotels look into in deciding to hire a new employee. The elements of competency which are communication, cognitive, leadership, problem-solving, and human relation was examined to identify their effects the hotel job offer decisions in Malaysia. Data required for this study was collected through self-administered questionnaires to 205 hotel human resources (HR) managers and personnel involved in selecting and recruiting employees. The data gathered were analysed using SPSS statistical tool, and was found that all elements of competency were positively related to HR's job offer decisions. The study highlights the element of problem-solving skills as the important element of competency that HR managers expects from fresh graduates.
\end{abstract}

Keywords: Fresh Graduate, Competency, Job Offer Decisions, Hotel Industry

\section{Introduction}

The hotel industry retains its position as one of the industries that emphasize highly on skills as part of their employees' work culture. Employees were trained to be ready to keep up different types of customers' needs and rapidly evolving service environment and technological change (Singh \& Munjal, 2012). In developing skilled and trained employees, the role of higher education institutions (HEI) should be part of the process. Internship program that enables students and future graduates to get the feel of the real working life in a hotel was widely practised throughout the world (Yang et al., 2016). This collaboration and knowledge transfer process helps in developing passion, competency and interest among the students prior to their early career in the hotel (Dhevabanchachai \& Wattanacharoensil, 2017).

Jaykumar et al (2014) highlighted the importance of managerial competency among graduates for them to understand the operation of a hotel. This will encourage graduates to 
further develop other skills and capabilities to facilitate their transition into early career in the hotel. However, there has been an increase interest in validating the involvement of HEI in developing skills and competencies of graduates towards their early career in the hotel (Chang \& Busser, 2020; Gebbels et al., 2020; Wang et al., 2019). Recent studies indicated that the increase was mainly attributed by fresh graduates' lack of commitment, competence and personality (Haldorai et al., 2019; Han, 2020; Wang et al., 2019). Addressing this lack of competence may directly affects the hotel's service standards. Employers take it serious when it comes to seeking college graduates with suitable skills and capabilities (Brown et al., 2016).

Hospitality HEls have collaborated with hotel industry in ensuring that their graduates met the requirement set by the hotels prior joining them as their initial career. Hospitality courses were tailored to the actual work and skills required in the hotel industry (Teng, 2013). Millar and Park (2013) asserted that HEls and hospitality managers were always recommended to work together to provide students with the desirable competencies and set of skills. The industry involvement on the development of new curriculum is another avenue in realizing the desired competencies among graduates. The idea is for these HEls to provide comprehensive, up-to-date and innovative sets of skills, competencies and curriculum development that would help in their career after graduating and endorsed by the hotel managers (Brennen, 2017; Hsu et al., 2017). Each industry had its preferences of selecting the employee based on their expected competencies. Employers may rely on employees' ability to perform well at their job to increase their company's competitiveness. After all, the quality of employee and their work outputs will have significant impact on overall organizational performance (Ohme \& Zacher, 2015). What remains unclear is which of these competencies that are actually needed and sought after by the hotels in today's hotel service environment.

\section{Literature Review \\ Competency}

Competence is defined as knowledge, abilities, skills, and attitudes in completion of a task which required in an organization depending on the extend of which it may need in different job and level within the organization (Hager \& Gonczi, 1996). Much of the previous and current literature on competency pays particular attention on performing and adapting the knowledge, skills and attitudes (KSA) that are needed to deliver the duties required by the organization (Brownell \& Chung, 2001; Vakola et al., 2007; Wang, 2013). In the hotel industry, competency is a crucial aspect which is tailored to the nature of the occupation itself. It has been demonstrated that competency plays an important role in shaping hotel employees' skills in providing quality services to the customers (Safavi \& Bouzari, 2019).

Over the years there have been few studies examining the competency attributes across different field and occupational tasks, which some suggested how competencies might contribute on individual level (Heinsman et al., 2008; Thompson \& Cole, 1997) while others distinguish the need on organizational level (De Vos et al., 2011; Jaykumar et al., 2014). Gaining knowledge might be the aim in terms of educating employees but it is still insufficient to ensure that they are competent in doing the job, hence it is important to include the important attributes of competency in developing skilful hotel front liners. There are several attributes highlighted by previous studies expected from fresh graduates such as the communication competency, cognitive competency, leadership competency, problem- 
solving competency and human relation competency (Brownell \& Chung, 2001; Crawford et al., 2014; Jaykumar et al., 2014; Lin, 2002; Safavi \& Bouzari, 2019; Tas, 1983; Wang, 2013).

\section{Communication Competency}

Research into communication competency has a long history. Communication or interpersonal competency is the main ingredient in making a diverse workforce such as hotels works as it should be (Argyris, 1965). Ruben (1976) described the importance of communication competency in the multicultural setting of work and how they can adapt to each other's understanding to work as a team. According to Mottet et al. (2012), interpersonal or communication competency is a transactional process between people in order to understand each other and they may be in different form of communication. From there, relationship between them will form and work cooperation may occur easily through teamwork. Communication competency was also described by Maes et al. (1997) to be important for students once they started their career, let alone in the labour-intensive industry such as the hotel industry.

Communication competency may be realized in various forms such as verbal, body language, act of listening, persuading, discussion and understanding through non-verbal cues (Holland \& Baird, 1968; Maes et al., 1997; Mottet et al., 2012; Ruben \& Kealey, 1979; Sulaiman Al Jahwari et al., 2016). What is most important is the interaction and volume of information exchanges between the individuals and groups in work process (Madera et al., 2011). In the hospitality industry where interaction between employees and customers are frequent, communication competency is important and essential for employees. Madera et al. (2011) reported how relationships between employees and customers may be affected if they are unable to understand each other in the diverse and multi-lingual setting of the hospitality industry.

\section{Cognitive Competency}

Cognitive competency is the ability to acquire, process and interpret information for the understanding of the skills or knowledge in the organization (Reed et al., 2001). In another study which set out to understand the importance of cognitive competency in the hotel setting, Noguchi et al. (2006) note that there are differences between individuals in processing a good and bad information that need to be taken into. The one that is more competent will be the one that are able to focus on the positive aspects of the information and deliver their work accordingly. Cognitive can be viewed as one of the career interventions in developing the perfect group of employees. However, in this case, assessing prospective employees with cognitive competency will be a recruitment mechanism that focuses on finding the right candidate even before they join the team. Fresh graduates who are able to envision the hotel organization's philosophy in understanding the needs and wants of their customers through cognitive ability and mindful of their role in acknowledging its importance will be an added advantage (Proudfoot et al., 2009).

\section{Leadership Competency}

Another important competency attribute in the hotel work setting for fresh graduates is the leadership attribute. Bryman (2004) asserted that leadership is the development of a character based on beliefs, principles, responsibilities, and role in managing a unit or organization. Leadership competent can be nourished through different approaches in the HEI as students' progresses in their study. The education framework or curriculum design 
that support the nurturing of a leader attributes in the campus is beneficial to the students. Crawford et al. (2014) draw our attention to the role of coursework and internship undergone by fresh graduates prior to starting a career in the hotel as important period of training on leadership attribute.

They may need to apply this attribute in the case of negotiating with their team, in resolving disputes and misunderstanding and providing ideas and motivational support for their colleagues at work in the future. On the individual level, leadership attributes constitute their personality in understanding each other and able to strengthen their bond. In a larger perspective such as the organizational level, ability to use leadership attributes (transformational, transactional or even servant leadership) complement their role in managing a more complex and structured work functions (Zoghbi-Manrique-de-Lara \& RuizPalomino, 2019). Leadership plays an important role to empower their team to achieve their goals. It can be done if leaders are willing to place their confidence in their subordinates and values their ideas and opinions for the betterment of the team and organization (Bryman, 2004).

\section{Problem-solving Competency}

Problem-solving competency, concerned with the ability to address issues and difficulties faced by the interaction of service between hotel employees and customers (Cushman et al., 1997). Problem-solving competency can be intuitive and spontaneous but the response will determine whether it is the right choice to do or otherwise (Heinsman et al., 2008). De Vos et al. (2011) point out that the ability to face challenges at work and resolve the non-routine situations is what managers expect from an employee. The decision that they make in resolving the issue must be based on knowledge, analyse the process, and their role to be proactive (Kong, 2013; Wang et al., 2019). Managers are looking for individuals with proactive personality and able to initiate the move of resolving any customers' problems and disputes between colleagues (Wang et al., 2019). Problem-solving attribute supports the function of having structural organization in the hotel as managers frequently empowers their subordinates in the downward direction to take control of any challenging situations before it gets any worst and tainted the image of the hotel in the absent of their managers (Safavi \& Bouzari, 2019).

\section{Human Relation Competency}

Working in the labour intensive environment as compared to manufacturing industry, hotel employees are required to have human relation skill as they interact with others on the job quit extensively (Collins, 2020). The hospitality industry relies heavily on personal services between their employees and customers. Therefore, human relation competency attribute is important to control the work scene. Yang et al. (2014) highlight the need for hotel graduates to be have positive mindset in preparing to work in the hotel as they will be working with people from diverse background and language. The relationship between colleagues in the hotel setting can be observed through the teamwork that they displayed. Positive relationship within the team enhances their value from the perspective of the hotel manager. Taking care of the work relationship in the hotel requires more than just basic human interaction skills. The vibe that they bring in to the team and positive attitude towards working alongside others is the essential contributing factors to human relation competency (Yang et al., 2014). 


\section{Job Offer Decisions}

A job offer decisions relates to invitation to work for any organization during the recruitment and selection process. Candidates that meet the specific requirements set by HR managers have high possibility to be offered a job. Despite the fact that most literature focuses on the organizational perspective in offering a job, other studies have also examined the responses of potential candidate in accepting a job offer and the effect of timing that would change their decision (Becker et al., 2010; Foster \& Diab, 2017). It all depends on the candidates' agreement on the terms and conditions in the job offer. Going through the process by which they were assessed would somehow affect their decision to accept or decline any job offer (Foster \& Diab, 2017). On the context of the organization itself, several key elements were reviewed and examined which eventually comes to the final decision whether to offer or not the specified job vacancy (Chun-Hsi et al., 2008). However, Becker et al (2010) argued that the extend of issues raised during the recruitment and selection process would also have an effect on the work relationship of the accepted candidate in the later stage. Therefore, candidates or fresh graduates with the right competency attributes would be able to absorb the pressure and progress.

\section{The Relationship between Competency on Job Offer Decision}

As reported by Shum et al (2018), hotel uses competency assessment on prospective employees or fresh graduates looking for a job because the assessment model was widely used in the process of selecting their employees. One thing that is certain is that the elements in the competency attributes were exactly what HR managers are aiming for in any candidates. For example, having good communication skills will help new employees to work together as a team. Other attributes such as cognitive and leadership attributes showed their maturity in their decisions relating to work-related process and even issues for that matter (Wang, 2013). In addition, positive work environment through mutual understanding on the importance of teamwork and upholding the corporate culture of the hotel helps the team to grow in their relationship (Yang et al., 2014). A conducive work environment pushes the boundary of service among hotel employees as they apply their competencies effectively on delivering the best service to customers. Most fresh graduates look for the best team to work with and added by their own abilities and skills to offer (Jameson \& Hargraves, 1990). Competencies possessed by the fresh graduates can be put into the job and expand their skills after gaining several years of working experience (Shum et al., 2018). Collectively, it is important to note that all of the competency attributes of fresh graduates may have significant impact on HR's job offer in the hotel industry. Therefore, this study intended to test the following hypotheses based on the existing literature and evidences on the matter. H1a: Communication competency positively influences offer decision.

$H 1 b$ : Cognitive competency positively influences job offer decision.

H1c: Leadership competency positively influences job offer decision.

H1d: Problem-solving competency positively influences job offer decision.

H1e: Human relation competency positively influences job offer decisions.

\section{Methodology \\ Research Design}

The research conducted is a descriptive study and causal in nature where it is to investigate the competency among fresh graduates and the factors of hotel job offer decision. The dimensions of competency in this study are communication competence, cognitive 
competence, leadership competence, problem-solving competence, and human relation competence. Therefore, the research is conducted to seek the relationship between these five major attributes for competency among fresh graduates and hotel job offer decisions through correlation analysis. In this research, a quantitative approach through a crosssectional study was used.

\section{Population \& Sampling}

The target population in this research was the Human Resource Manager or other personnel in-charge of recruiting and selecting new employees from hotels in Kuala Lumpur. The sampling frame that was applied for this research was the list of hotels in Kuala Lumpur. The list of those hotels can be acquired from every booking website on the internet such as Agoda.com and Booking.com. There are about 435 hotels available in Kuala Lumpur which varies in facilities and extend of services based on their star rating (Ministry of Tourism, 2013).

\section{Sampling Technique \& Sample Size}

In this research, non-probability sampling which is purposive sampling was chosen as the respondents are HR managers and personnel with specific tasks of recruiting and selecting new employees as their main duty and expertise. In the later stage, snowball sampling was also applied to reach target number of respondents based on the recommendation of participated respondents in early stage. The sample for this research is the actual number of Human Resource Manager chosen as a sample that will represent the population of all Human Resource Manager from all hotels in Kuala Lumpur. As mentioned above, through the list of hotels that exist all over Kuala Lumpur, the actual sample can be acquired. A minimum of 30 respondents to a maximum of 500 respondents are the most suggested sample size for most research according to Roscoe (1975) rules of thumb. Therefore, for this research, it will need at least 205 Human Resources Manager from those 435 hotels in Kuala Lumpur to gain the best result can be achieved from this research.

A closed-ended questionnaire through rating scale questions was used in this research. The questionnaire was developed based on the variable that was identified in the early stage in the conceptual study framework. In this research, to acquire the reliability level of the questionnaire that was used for the entire study, a pilot test on the questionnaire was conducted first. This pilot test required a small sample at least $1 / 3$ of the sample for this research. The test was completed within a reasonable period and necessary amendments was made to improve the instrument. The finalized questionnaire was divided into several sections that consist of demographic profile, competency among fresh graduate, and the best factors that will influence the job offer decisions by Human Resource Manager. The questionnaire was in the form of a 5-point Likert scale. The questionnaire was made available in dual language which were English and Malay as the medium of communication. 
Table 3.1: Measures of the study variables

\begin{tabular}{|c|c|c|c|}
\hline Study Variables & $\begin{array}{l}\text { No. } \\
\text { of } \\
\text { ltems }\end{array}$ & $\begin{array}{l}\text { Sources of } \\
\text { Instrument Items }\end{array}$ & Type of Scale \\
\hline $\begin{array}{l}\text { Competency Attributes } \\
\text { Communication } \\
\text { Cognitive } \\
\text { Leadership } \\
\text { Problem Solving } \\
\text { Human Relations }\end{array}$ & $\begin{array}{l}4 \\
4 \\
4 \\
4 \\
4\end{array}$ & $\begin{array}{l}\text { Holland and Baird } \\
\text { (1968), } \\
\text { Brownell and Chung } \\
(2001), \& \\
\text { Crawford et al. } \\
\text { (2014), }\end{array}$ & $\begin{array}{l}\text { A five-point Likert-scale from } \\
\text { (1) "Strongly Disagree" to (5) } \\
\text { "Strongly Agree" }\end{array}$ \\
\hline Job Offer Decisions & 5 & $\begin{array}{l}\text { van Rheede et al. } \\
\text { (2009) }\end{array}$ & $\begin{array}{l}\text { A five-point Likert-scale from } \\
\text { (1) "Strongly Disagree" to (5) } \\
\text { "Strongly Agree" }\end{array}$ \\
\hline $\begin{array}{l}\text { Demographic \& Work } \\
\text { Profile Information }\end{array}$ & 8 & & $\begin{array}{l}\text { Selection of nominal \& } \\
\text { ordinal scales }\end{array}$ \\
\hline
\end{tabular}

\section{Plan for Data Collection}

The data of the research was collected with hotels in a particular area which was in Kuala Lumpur, Malaysia. The reason for choosing Kuala Lumpur as the place for our research was because its density of hotels located in the state as compared to other states. There were about 435 hotels in Kuala Lumpur which varies through their star rating. A set of questionnaires will be distributed for the Human Resource Manager to answer and give feedback. Data collection was done by contacting potential respondents through phone calls and emailing them the self-administered questionnaire as Movement Control Order (MCO) was enforced by the Malaysian government in 2020 and 2021 that restricts the possibility for researchers to personally obtain feedbacks.

\section{Findings}

The data was collected from respondents after a month of fieldwork. The Human Resource Managers were selected because they were responsible and experienced in recruiting fresh graduates as an employee. A total of 205 sets of questionnaires were received and analysed.

\section{Respondents' Demographic and Work Profiles}

The following Table 4.1 outlines the respondents' demographic and work profiles which include gender, age, marital status, educational qualification, hotel tenure, industry tenure, and position tenure. 
Table 4.1: Respondents' Demographic Profiles

\begin{tabular}{|c|c|c|c|}
\hline Profiles & Categories & Frequencies & Percentage (\%) \\
\hline \multirow[t]{2}{*}{ Gender } & Male & 51 & 24.9 \\
\hline & Female & 154 & 75.1 \\
\hline \multirow[t]{5}{*}{ Age } & Between $18-29$ years & 45 & 22.0 \\
\hline & old & 73 & 35.6 \\
\hline & $30-34$ years old & 63 & 30.7 \\
\hline & $35-40$ years old & 24 & 11.7 \\
\hline & More than 40 years old & & \\
\hline \multirow[t]{4}{*}{ Marital Status } & Single & 90 & 43.9 \\
\hline & Married & 100 & 48.8 \\
\hline & Divorced & 13 & 6.3 \\
\hline & Widow/Widower & 2 & 1.0 \\
\hline Education & Certificate & 3 & 1.5 \\
\hline \multirow[t]{4}{*}{ Qualification } & Diploma & 28 & 13.7 \\
\hline & Bachelor's degree & 136 & 66.3 \\
\hline & Masters & 25 & 12.2 \\
\hline & Others & 13 & 6.3 \\
\hline \multirow[t]{5}{*}{ Hotel Tenure } & Less than 6 months & 51 & 24.9 \\
\hline & 6 months - 1 year & 31 & 15.1 \\
\hline & $2-3$ years & 48 & 23.4 \\
\hline & $4-5$ years & 36 & 17.6 \\
\hline & More than 5 years & 39 & 19.0 \\
\hline \multirow[t]{5}{*}{ Industry Tenure } & Less than 1 year & 5 & 2.4 \\
\hline & $1-3$ years & 20 & 9.8 \\
\hline & $4-5$ years & 58 & 28.3 \\
\hline & $6-9$ years & 85 & 41.5 \\
\hline & More than 9 years & 37 & 18.0 \\
\hline \multirow[t]{5}{*}{ Position Tenure } & Less than 6 months & 7 & 3.41 \\
\hline & 6 months - 1 year & 28 & 13.7 \\
\hline & $2-3$ years & 50 & 24.4 \\
\hline & $4-5$ years & 90 & 43.9 \\
\hline & More than 5 years & 30 & 14.6 \\
\hline
\end{tabular}

As stated in Table 4.1, it shows that out of 205 respondents, there is 75.1 per cent which equals to 154 female respondents and 24.9 per cent male which equals to 51 respondents. In term of age, the highest numbers of respondents are from the range of age of 30 to 34 years old or 35.6 per cent, followed by age range from 35 to 40 years old with 30.7 per cent. While the rest than 40 years old with 11.7 per cent, followed by age range from 35 to 40 years old with 14.1 per cent. Most of the respondents are married with 48.8 per cent, followed by single respondents with 43.9 per cent, and the remaining were 7.3 per cent. According to the data gathered, the highest education patrons are from the bachelor's degree with 66.3 per cent, followed by diploma holder with 13.7 per cent, and then followed by master's holder with 12.2 per cent, and the rest were certified holder and others qualification respectively 1.5 per cent and 6.3 per cent. 
According to the data gathered, the highest hotel tenure patrons are those who worked for less than six months with 24.9 per cent, followed by two to three years with 23.4 per cent, and then those who worked more than five years with 19.0 per cent, and those who worked for four to five years with 17.6 per cent and the from six to one year with 15.1 per cent. The highest industry tenure was recorded from six to nine years with 41.5 per cent, and then the second highest was from four to five years respectively 28.3 per cent, followed by the rest. The highest number of respondents with HR position tenure 43.9 per cent were from four to five years at the position which explains their experiences in the job. HR managers with vast working experiences are able to work together with different groups of employees and understand their needs (Ravichandran et al., 2017). The inclusion of their tenure in the study was to ensure that they were capable of selecting the desired candidates based on the attributes that they are looking for.

\section{Reliability Analysis}

Cronbach's coefficient alpha is the most used statistic especially in terms of measuring the internal consistency of a scale (Pallant, 2016). The Cronbach's Alpha Coefficient value for all the independent variables in the study revealed a range of coefficient values from .880 to .716. The independent variable that has the highest coefficient value is leadership with a value of .880 , followed by cognitive with a value of .851 , and then human relation with a value of .757, problem-solving with a value of .716, and communication with a value of .741. As for the dependent variable, it is also accepted as the reliability coefficient is .735.

Table 4.2: Reliability Coefficient Values of Study Variables

\begin{tabular}{lll}
\hline Variables & $\begin{array}{l}\text { Number of Scale } \\
\text { Items }\end{array}$ & $\begin{array}{l}\text { Cronbach's Alpha } \\
\text { Coefficient }(\boldsymbol{\alpha})\end{array}$ \\
\hline Communication & 4 & .741 \\
Cognitive & 4 & .851 \\
Leadership & 4 & .880 \\
Problem Solving & 4 & .716 \\
Human Relation & 4 & .757 \\
Job Offer Decisions & 5 & .735 \\
& & \\
\hline
\end{tabular}

\section{Pearson Correlations Analysis of Competencies and Job Offer Decisions}

According to Pallant (2016), the Pearson product-moment correlation coefficient analysis is used to evaluate and explore the correlation relationship and direction between a study's variables. She went on to say that a minor correlation is enough to gain statistical significance with a big sample size $(\mathrm{N}>100)$. Small or moderate correlations that do not even achieve statistical significance at the level of $p<0.05$ with a small sample size, on the other hand, are acceptable (Pallant, 2016). 
Table 4.3: Pearson Product-Moment Correlations Matrix of Competencies Attributes and Job Offer Decisions

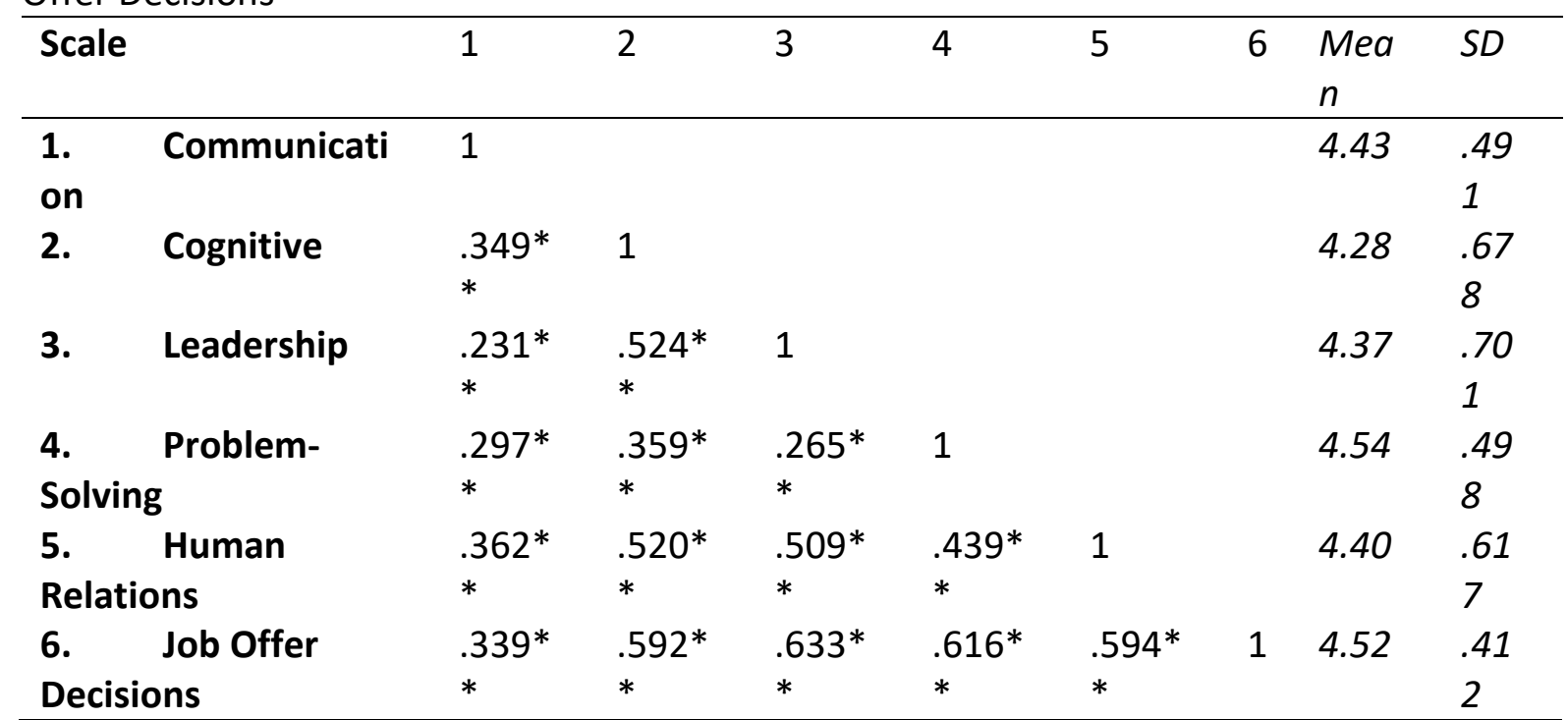

Note: $\mathrm{N}=205,{ }^{* *} p<0.01$

As shown in the Table 4.3 above, a Pearson product-moment correlation coefficient was computed to assess the relationship between the competencies attributes and job offer decisions. There was a positive correlation between the communication attribute and job offer decisions, $r=.339$ ( $p<0.01)$. The relationship between cognitive attribute and job offer decisions is largely significant correlated $(r=.592, p<0.01)$. In addition, there was a positive correlation between the leadership attribute and job offer decisions, $r=.633(p<0.01)$. The correlation between the problem-solving attribute and job offer decisions also showed significant positive relationship with $r=.616(p<0.01)$. Lastly was a positive correlation between the human relations attribute and job offer decisions, $r=.594(p<0.01)$.

\section{The Important Attribute of Competency on Job Offer Decisions}

Using multiple linear regression analysis, the effects of five competencies attributes on job offer decisions were examined. Preliminary analyses were carried out to ensure that the normality, linearity, multicollinearity, and homoscedasticity assumptions were not violated. The result showed that there were significant positive correlations between the attributes and job offer decisions. The total variances explained by the problem-solving attribute on job offer decisions were 66.5 per cent with a coefficient of the relationship value ( $R^{2}$ value) of 0.665 . As shown in the Table 4.4 below, the result was also suggested that problem-solving attribute was a significant competency attribute that affect job offer decisions in this study $(p=.000)$. 
Table 4.4: Results of the Multiple Regressions of Competencies Attributes on Job Offer Decisions

\begin{tabular}{llll}
\hline Variables & $\boldsymbol{\beta}$ & $\boldsymbol{T}$ & $\boldsymbol{p}$ \\
\hline Communication & .270 & .818 & .550 \\
Cognitive & $.185^{* * *}$ & .603 & .001 \\
Leadership & $.358^{* * *}$ & .648 & .000 \\
Problem-Solving & $.387^{* * *}$ & .769 & .000 \\
Human Relation & $.135^{* * *}$ & .575 & .013 \\
\hline
\end{tabular}

*** $p<0.05 ; R 2=.664 ;$ F-value $=79.007$

\section{Summary of Hypothesis Testing}

The summary of the hypothesis testing as reported in Table 4.3 found that all five competencies attributes which are communication, cognitive, leadership, problem-solving and human relation were having positively significant influences on job offer decisions. Hypothesis $1(\mathrm{H} 1)$ proposed the relationship between competencies attributes and job offer decisions by Human Resource Manager in Kuala Lumpur's hotels. The primary concern was the influence of Human Resource Managers' perceptions of employees' communication skills, cognitive skills, ability to lead a team, problem-solving skills, and human relations on their job offer decisions to potential fresh graduates.

Table 4.5: Summary of Hypothesis Testing

\begin{tabular}{llll}
\hline Hypothesis & $\begin{array}{l}\text { Regression } \\
\text { Statistical } \\
\text { Significance }\end{array}$ & Result \\
\hline $\mathrm{H} 1 \mathrm{a}$ & Communication influences Job Offer Decisions & .270 & Reject \\
$\mathrm{H} 1 \mathrm{~b}$ & Cognitive influences Job Offer Decisions & $.185^{* * *}$ & Accept \\
$\mathrm{H} 1 \mathrm{c}$ & Leadership influences Job Offer Decisions & $.358^{* * *}$ & Accept \\
$\mathrm{H} 1 \mathrm{~d}$ & Problem-Solving influences Job Offer Decisions & $.387^{* * *}$ & Accept \\
$\mathrm{H} 1 \mathrm{e}$ & Human Relations influences Job Offer Decisions & $.135^{* * *}$ & Accept \\
\hline
\end{tabular}

${ }^{*} p<0.05$

$* * p<0.01$

$* * *$ Correlation significant at $p<0.05$ (2-tailed)

\section{Discussion}

The main focus of the discussion was to address the objectives of the study and the research questions set earlier in the study. The initial objective was to examine the influence of fresh graduates' competency in relation to job offer decision by the HR Managers. Therefore, the second objective was to identify which competency attribute is the most important one sought by Human Resource Manager.

Based on findings presented, Hypothesis 1a $(\mathrm{H} 1 \mathrm{a})$ proves that there is insignificant relationship between communication competency and job offer decisions. Hospitality managers are concerned and ensure that their employees acquire job-related skills and focus on good communication as one of the competencies (Itani et al., 2015). Another interesting finding was cognitive skill with a positive relationship on job offer decisions by HR. Lent and 
Brown (2013) asserted that cognitive competency helps in the journey of employee to become successful, and facilitate their progression to become a manager.

The result also indicated that leadership competency positively related to job offer decision, where hotel insist on the leadership character to be one of the important attributes that will see future manager in the pipeline (Karatepe et al., 2020). High creativity skills and strong leadership attribute will facilitate effective decision making and management of the hotel team (Zoghbi-Manrique-de-Lara \& Ruiz-Palomino, 2019). The nature of hotel operation and services are more incline towards working with people from all sorts of background. Human relations competency as found in this study is one of the required aspects for hotels which corroborate the idea of service in the hotel industry (Lee et al., 2015).

The relationship between problem-solving competency and job offer decision shows the strongest relationship. This finding seem to be consistent with those of Kenny et al. (2014) where hotel managers seek to have employees that are able to meet customers' expectations and address their needs. Yang et al. (2016) believe that graduates with problem-solving skill able to gain the trust of their future employer. A possible explanation for the need of this attribute is that when working in the current pandemic period where new sets of standard has to change and less personal service with customers is warranted. In addition, Velo and Mittaz (2006) stated that an employee who are able to address problems faced by customers in an instant will be beneficial on both personal and organizational level. Not much can be expected from a fresh graduate in terms of skills and competency but the their ability to try and apply what they have learn into practice is highly appreciative (Gbadamosi et al., 2015).

\section{Conclusion}

Fresh graduates are the next generation of employees which comes with different set of skills and knowledge that is currently needed for the job. Making sure that they are ready to deliver what it takes to be a hotel employee depends on their skills and personality. Employing a fresh graduate with the ability to perform well is an added advantage for the hotel. Based on the objective of this study, the researchers were able to conclude that competency attributes are essential for HR managers in their decision to employ new employees. From the findings, what is most important for students or fresh graduates is to obtain as much knowledge and skills that will set them apart from other candidates in applying for a job in the hotel. Each of the attributes showed the importance for fresh graduates to be optimistic, reliable and ready in seeking their early career in the hotel industry.

Starting their career in the pandemic period requires them to be flexible, vigilant and innovative in providing quality services to customers. It will be a good training ground for them to understand and adapt to different work situations which was not taught in their previous study period. Fresh graduates need to be motivated to learn and apply different sets of skills and attributes in this difficult period as less contact with customers will require them to revised their service standards. Strategies on matching these attributes and hotel requirement during this pandemic period is essential for HEls in order for their graduates to be offered a job while most hotels put a hold on new employment exercise. Future studies are recommended for HEls to look on the extend of the competency attributes that can be adapted by fresh graduates in post-pandemic period and its effectiveness on new hotel operating service standards. 


\section{References}

Argyris, C. (1965). Explorations in interpersonal competence-I. The Journal of Applied Behavioral Science, 1(1), 58-83.

Becker, W. J., Connolly, T., \& Slaughter, J. E. (2010). The effect of job offer timing on offer acceptance, performance and turnover. Personnel Psychology, 63.

Brennen, P. G. (2017). Experiential Learning in Hospitality Management Education (Publication Number UMI No: 10262664) [Doctoral Dissertation, Northeastern University Boston]. ProQuest Dissertations and Theses database.

Brown, E. A., Bosselman, R. H., \& Thomas, N. J. (2016). Are hospitality graduates making too many compromises? What they give up may lead to turnover. Journal of Human Resources in Hospitality \& Tourism, 15(2), 133-146. .https://doi.org/10.1080/15332845.2016.1084853

Brownell, J., \& Chung, B. G. (2001). The Management Development Program: A CompetencyBased Model for Preparing Hospitality Leaders. Journal of Management Education, 25(2), 124-145. https://doi.org/10.1177/105256290102500203

Bryman, A. (2004). Qualitative research on leadership: A critical but appreciative review. The Leadership Quarterly, 15(6), 729-769. https://doi.org/10.1016/j.leaqua.2004.09.007

Chang, W., \& Busser, J. A. (2020). Hospitality career retention: the role of contextual factors and thriving at work. International Journal of Contemporary Hospitality Management, 32(1), 193-211. https://doi.org/10.1108/ijchm-10-2018-0831

Chun-Hsi, V. C., Hsu-Mei, L., \& Ying-Jung, Y. Y. (2008). The antecedent and consequence of person-organization fit: Ingratiation, similarity, hiring recommendations and job offer. International Journal of Selection and Assessment, 16(3), 210-219.

Collins, G. R. (2020). Improving human-robot interactions in hospitality settings. International Hospitality Review, 34(1), 61-79. https://doi.org/10.1108/ihr-09-20190019

Crawford, A., Weber, M. R., \& Dennison, D. (2014). Using Hospitality Coursework and Internships to Develop Student Leadership Abilities. Journal of Teaching in Travel \& Tourism, 14(4), 386-406. https://doi.org/10.1080/15313220.2014.963189

Cushman, J., Dilly, G., \& Gould, R. (1997). Applying the Problem-Solving Method to Hospitality Education. Journal of Hospitality \& Tourism Education, 9(4), 60-62. https://doi.org/10.1080/10963758.1997.10685355

De Vos, A., De Hauw, S., \& Van der Heijden, B. I. J. M. (2011). Competency development and career success: The mediating role of employability. Journal of Vocational Behavior, 79(2), 438-447. https://doi.org/10.1016/j.jvb.2011.05.010

Dhevabanchachai, N., \& Wattanacharoensil, W. (2017). Students expectations experiences and career direction after in house internship the pedagogical role of the hotel training center in Thailand. Journal of Teaching in Travel \& Tourism, 17(2), 118-134. https://doi.org/10.1080/15313220.2017.1312663

Foster, C. C., \& Diab, D. L. (2017). To accept or not to accept a job offer: Examining inaction inertia in an organizational context. Journal of Applied Social Psychology, 47(11), 634645. https://doi.org/10.1111/jasp.12468

Gbadamosi, G., Evans, C., Richardson, M., \& Ridolfo, M. (2015). Employability and students' part-time work in the UK: does self-efficacy and career aspiration matter? British Educational Research Journal, n/a-n/a. https://doi.org/10.1002/berj.3174

Gebbels, M., Gao, X., \& Cai, W. (2020). Let's not just "talk" about it: reflections on women's career development in hospitality. International Journal of Contemporary Hospitality 
Management, ahead-of-print(ahead-of-print). https://doi.org/10.1108/ijchm-052020-0385

Hager, P., \& Gonczi, A. (1996). What is competence? Medical Teacher, 18(1), 15-18. https://doi.org/https://doi.org/10.3109/01421599609040255

Haldorai, K., Kim, W. G., Pillai, S. G., Park, T., \& Balasubramanian, K. (2019). Factors affecting hotel employees' attrition and turnover: Application of pull-push-mooring framework. International Journal of Hospitality Management, 83, 46-55.

https://doi.org/10.1016/j.ijhm.2019.04.003

Han, J. W. (2020). A review of antecedents of employee turnover in the hospitality industry on individual, team and organizational levels. International Hospitality Review, aheadof-print(ahead-of-print). https://doi.org/10.1108/ihr-09-2020-0050

Heinsman, H., Hoogh, A. H. B. d., Koopman, P. L., \& Muijen, J. J. v. (2008). Commitment, control, and the use of competency management. Personnel Review, 37(6), 609-628. https://doi.org/10.1108/00483480810906865

Holland, J. L., \& Baird, L. L. (1968). An interpersonal competency scale. Educational and Psychological Measurement, 28, 503-510.

Hsu, C. H. C., Xiao, H., \& Chen, N. (2017). Hospitality and tourism education research from 2005 to 2014. International Journal of Contemporary Hospitality Management, 29(1), 141-160. https://doi.org/10.1108/ijchm-09-2015-0450

Itani, S., Järlström, M., \& Piekkari, R. (2015). The meaning of language skills for career mobility in the new career landscape. Journal of World Business, 50(2), 368-378. https://doi.org/10.1016/j.jwb.2014.08.003

Jameson, S. M., \& Hargraves, S. (1990). A comparative analysis of the job opportunities offered to hotel graduates. Personnel Review, 19(6), 25-32.

Jaykumar, V., Fukey, L. N., \& Balasubramanian, K. (2014). Hotel Managers Perspective of Managerial Competency among Graduating Students of Hotel Management Programme. Procedia - Social and Behavioral Sciences, 144, 328-342. https://doi.org/10.1016/j.sbspro.2014.07.303

Karatepe, O. M., Aboramadan, M., \& Dahleez, K. A. (2020). Does climate for creativity mediate the impact of servant leadership on management innovation and innovative behavior in the hotel industry? International Journal of Contemporary Hospitality Management, 32(8), 2497-2517. https://doi.org/10.1108/ijchm-03-2020-0219

Kenny, M. E., Medvide, M. B., Minor, K. A., Walsh-Blair, L. Y., Bempechat, J., Seltzer, J. M. R., \& Blustein, D. L. (2014). A Qualitative Inquiry of the Roles, Responsibilities, and Relationships Within Work-Based Learning Supervision. Journal of Career Development, 42(2), 117-132. https://doi.org/10.1177/0894845314543496

Kong, H. (2013). The Influence of Hotel Organizational Career Management on Career Competencies. In Z. Zhang, R. Zhang, \& J. Zhang, LISS 2012 Berlin, Heidelberg.

Lee, A. P., Teng, H.-Y., \& Chen, C.-Y. (2015). Workplace Relationship Quality and Employee Job Outcomes in Hotel Firms. Journal of Human Resources in Hospitality \& Tourism, 14(4), 398-422. https://doi.org/10.1080/15332845.2015.1002068

Lent, R. W., \& Brown, S. D. (2013). Social cognitive model of career self-management : Toward a unifying view of adaptive career behavior across the life span. Journal of Counseling Psychology, 60(4), 557-568.

Lin, S.-C. (2002). Exploring the Relationships Between Hotel Management Courses and Industry Required Competencies. Journal of Teaching in Travel \& Tourism, 2(3), 81-101. https://doi.org/10.1300/J172v02n03_05 
Madera, J. M., Dawson, M., Madera, J. M., \& Neal, J. A. (2011). Managing bilingual employees: communication strategies for hospitality managers. Worldwide Hospitality and Tourism Themes, 3(4), 319-334. https://doi.org/10.1108/17554211111162444

Maes, J. D., Weldy, T. G., \& Icenogle, M. L. (1997). A managerial perspective: Oral communication competency is most important for business students in the workplace. The Journal of Business Communication, 34(1), 67-80.

Millar, M., \& Park, S.-Y. (2013). Sustainability in Hospitality Education: The Industry's Perspective and Implications for Curriculum. Journal of Hospitality \& Tourism Education, 25(2), 80-88. https://doi.org/10.1080/10963758.2013.805090

Ministry of Tourism. (2013). Minimum Requirements for Star Rating of Hotel. Ministry of Tourism.

Mottet, T. P., Vogl-Bauer, S., \& Houser, M. L. (2012). Your interpersonal communication Pearson.

Noguchi, K., Gohm, C. L., \& Dalsky, D. J. (2006). Cognitive tendencies of focusing on positive and negative information. Journal of Research in Personality, 40(6), 891-910. https://doi.org/10.1016/j.jrp.2005.09.008

Ohme, M., \& Zacher, H. (2015). Job performance ratings: The relative importance of mental ability, conscientiousness, and career adaptability. Journal of Vocational Behavior, 87, 161-170. https://doi.org/10.1016/j.jvb.2015.01.003

Pallant, J. (2016). SPSS Survival Manual (6th ed.). McGraw-Hill.

Proudfoot, J. G., Corr, P. J., Guest, D. E., \& Dunn, G. (2009). Cognitive-behavioural training to change attributional style improves employee well-being, job satisfaction, productivity, and turnover. Personality and Individual Differences, 46(2), 147-153. https://doi.org/10.1016/j.paid.2008.09.018

Ravichandran, S., Israeli, A. A., Sethna, F., Bolden, E. C., \& Ghosh, A. (2017). Hospitality managers' importance perceptions of human resource practices related to employment of foreign workers in the United States. Journal of Human Resources in Hospitality \& Tourism, 16(4), 331-348. https://doi.org/10.1080/15332845.2017.1266857

Reed, C. A., Reardon, R. C., Lenz, J. G., \& Leierer, S. J. (2001). A cognitive career course: From theory to practice. The Career Development Quarterly, 50(December), 158-167.

Roscoe, J. T. (1975). Fundamental research statistics for the behavioural sciences (2nd ed.). Holt, Rinehart and Winston.

Ruben, B. D. (1976). Assessing communication competency for intercultural adaptation. Group \& Organization Studies, 1(3), 334-354.

Ruben, B. D., \& Kealey, D. J. (1979). Behavioral assessment of communication competency and the prediction of cross-cultural adaptation. International Journal of Intercultural Relations, 3, 15-47.

Safavi, H. P., \& Bouzari, M. (2019). The association of psychological capital, career adaptability and career competency among hotel frontline employees. Tourism Management Perspectives, 30, 65-74. https://doi.org/10.1016/j.tmp.2019.02.001

Shum, C., Gatling, A., \& Shoemaker, S. (2018). A model of hospitality leadership competency for frontline and director-level managers: Which competencies matter more? International Journal of Hospitality Management, 74, 57-66. https://doi.org/10.1016/j.ijhm.2018.03.002

Singh, A., \& Munjal, S. (2012). Issues and concerns in technology decisions: the hotel operator's perspective. Worldwide Hospitality and Tourism Themes, 4(2), 174-184. 
Sulaiman Al Jahwari, D., Sirakaya-Turk, E., \& Altintas, V. (2016). Evaluating communication competency of tour guides using a modified importance-performance analysis (MIPA). International Journal of Contemporary Hospitality Management, 28(1), 195-218. https://doi.org/10.1108/ijchm-02-2014-0064

Tas, R. F. (1983). Competencies important for hotel manager trainees (Publication Number UMI No: 8414189) [Doctoral Dissertation, Oklahoma State University]. ProQuest Dissertations \& Theses.

Teng, C.-C. (2013). Developing and evaluating a hospitality skill module for enhancing performance of undergraduate hospitality students. Journal of Hospitality, Leisure, Sport \& Tourism Education, 13, 78-86. https://doi.org/10.1016/j.jhlste.2013.07.003

Thompson, J., \& Cole, M. (1997). Strategic competency - the learning challenge. Journal of Workplace Learning, 9(5), 153-162. https://doi.org/10.1108/13665629710169611

Vakola, M., Soderquist, K. E., \& Prastacos, G. P. (2007). Competency management in support of organisational change. International Journal of Manpower, 28(3/4), 260-275. https://doi.org/10.1108/01437720710755245

van Rheede, A., Tromp, D., \& Blomme, R. J. (2009). Perceptions of job and hospitality industry characteristics on career decisions. Advances in Hospitality and Leisure, 5, 51-68. https://doi.org/10.1108/s1745-3542(2009)0000005007

Velo, V., \& Mittaz, C. (2006). Breaking into emerging international hotel markets: Skills needed to face this challenge and ways to develop them in hospitality management students. International Journal of Contemporary Hospitality Management, 18(6), 496508. https://doi.org/10.1108/09596110610681539

Wang, Y.-F. (2013). Constructing career competency model of hospitality industry employees for career success. International Journal of Contemporary Hospitality Management, 25(7), 994-1016. https://doi.org/10.1108/ijchm-07-2012-0106

Wang, Z., Yu, K., Xi, R., \& Zhang, X. (2019). Servant leadership and career success: the effects of career skills and proactive personality. Career Development International, 24(7), 717-730. https://doi.org/10.1108/cdi-03-2019-0088

Yang, H., Cheung, C., \& Song, H. (2016). Enhancing the learning and employability of hospitality graduates in China. Journal of Hospitality, Leisure, Sport \& Tourism Education, 19, 85-96. https://doi.org/10.1016/j.jhlste.2016.08.004

Yang, L.-T., Partlow, C. G., Anand, J., \& Shukla, V. (2014). Assessing the Competencies Needed by Hospitality Management Graduates in India. Journal of Hospitality \& Tourism Education, 26(4), 153-165. https://doi.org/10.1080/10963758.2014.959963

Zoghbi-Manrique-de-Lara, P., \& Ruiz-Palomino, P. (2019). How servant leadership creates and accumulates social capital personally owned in hotel firms. International Journal of Contemporary Hospitality Management, 31(8), 3192-3211.

https://doi.org/10.1108/ijchm-09-2018-0748 